\title{
Increasing High Order Thinking Skill (HOTS) Using Question Card Games on Social Studies Content in Class V of Kranji XVI Public Elementary School, Bekasi City
}

\author{
Pepy Susanti; M. Syarif Sumantri; Sarkadi \\ Universitas Negeri Jakarta, Indonesia \\ http://dx.doi.org/10.18415/ijmmu.v8i2.2446
}

\begin{abstract}
This research was motivated by the low HOTS in SDN Kranji XVI Bekasi City. This study focuses on the efforts of researchers to improve HOTS in social studies learning. This research aims to see the increase in HOTS of students through social studies learning by applying card games to the concept of natural disasters in grade V SD. To achieve this goal, classroom action research was conducted using the model of Kemmis and Mc Taggart which consisted of two cycles, each of which consisted of four actions. The instruments used were questions to measure student HOTS and observation sheets to store student and teacher activities in learning. The subjects in this study were 30 grade V SD students. The results obtained during the implementation of classroom action research showed that the relevant question card games were applied in social studies learning to develop student HOTS. In the first cycle, the proportion of student completeness on HOTS reached $66.67 \%$, while in the second cycle it reached $86.67 \%$. The results of observations of teacher performance and student activities reached a proportion of $100 \%$ in cycle II of the cycle I which only obtained the proportions of $84.09 \%$ and $75 \%$. Thus, it can be ignored that the application of question card games in social studies learning can increase student HOTS.
\end{abstract}

Keywords: High Order Thinking Skill (HOTS); Question Card Games; Social Studies Learning; Elementary School Students

\section{Introduction}

The low quality of social studies learning in elementary schools should make immediate improvements to the social studies learning process (Setiawan, Juniarso, et al., 2020; Setiawan \& Iasha, $2020 b$ ). This presents a challenge for teachers to continuously seek alternative solutions to improve social studies learning in the HOTS category (Sudrajat et al., 2018).

HOTS is closely related to thinking skills (Sari, Luvita, et al., 2020; Setiawan, 2015; Setiawan, Rachmadtullah, et al., 2020). The demand for thinking skills in the 2013 curriculum is in line with Krathwohl's opinion that indicators for measuring higher thinking skills include analyzing, evaluating, and creating/creating: (1) analyzing: students are skilled in separating material into parts -part of its arrangement and detect how a part relates to one part of it to another; (2) evaluating: students are skilled 
in making decisions based on standard criteria (3) creating: students are skilled in planning a way to make a design to complete a given task and complete it (Lewy, Zulkardi, and Aisyah, 2009). This component of thinking skills must be explored in elementary school learning, especially social studies learning (Sari, MS, et al., 2020; Yetti et al., 2021).

HOTS is very much needed to explore the learning process in SD because based on the results of observations in Class V (six) SDN Kranji XVI Kota Bekasi shows that (1) students who stand out in class tend to be the same person in every meeting, (2) students who are skilled at solving questions in every meeting are less care to share with other students, (3) students still have difficulty understanding the questions, (4) students are not able to separate the important parts in the questions to be used as keys to solving questions, (5) students are not yet skilled in doing something new and have not been exemplified by the teacher, (6) the initial score of students in working on High Order Thinking Skill questions (category of analyzing questions) was 10 students complete (33\%) with a class average score of 62.71 while the applicable KKM achievements in school were $\geq 73$ and classical completeness $\geq 85 \%$.

Then the initial dialogue with the class teacher, from these problems and the HOTS demands of students in the 2013 curriculum that were entrusted to the teacher, the researchers, and the teacher agreed that there was a need for classroom learning with challenging questions for students to be skilled and further explore the knowledge that was they have but also packed with fun learning strategies so that students don't get bored and prefer the content of social science in each theme in grade V Elementary School. The average value on the daily test even semester of the 2019/2020 school year in class V SDN Kranji XVI Bekasi City on social studies learning is more clearly shown in Figure 1.

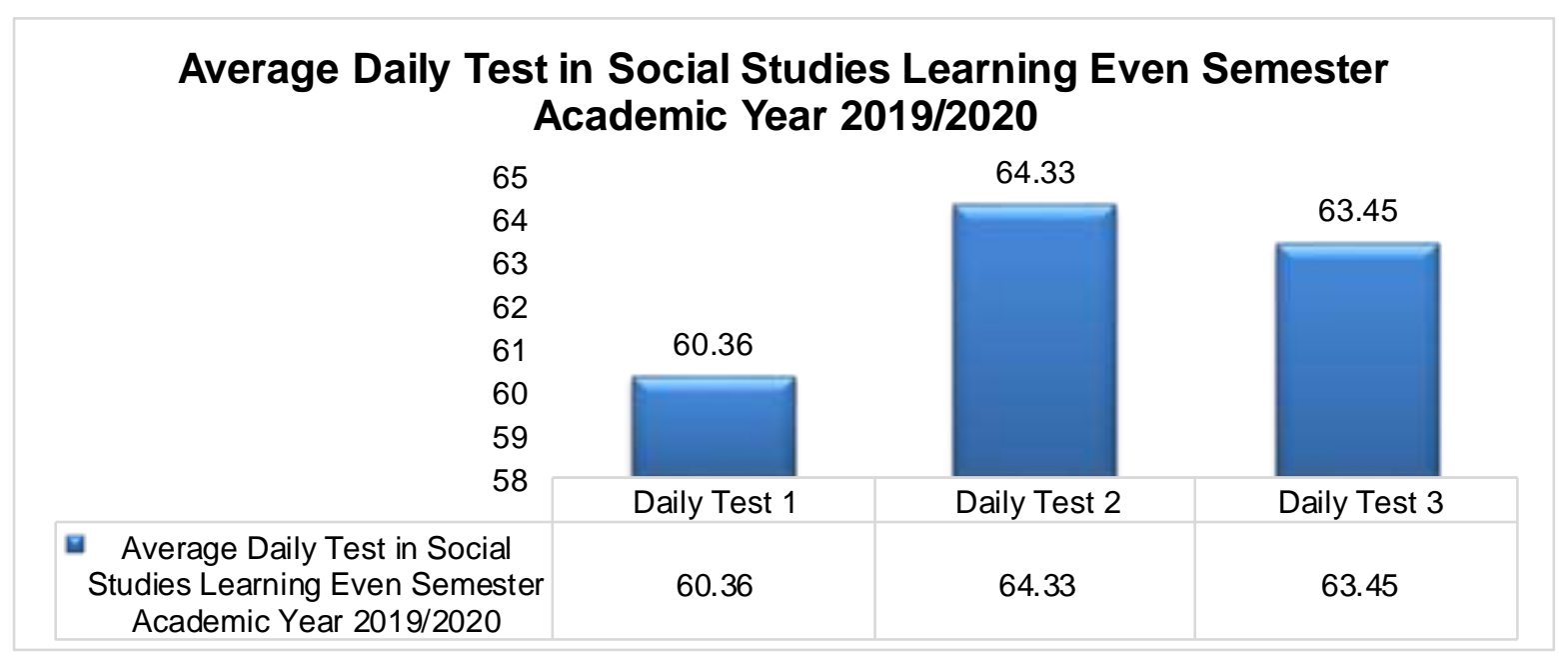

Figure 1. Average Daily Test Values for Class V SDN Kranji XVI Bekasi City in Social Studies Learning for the 2019/2020 Academic Year

Based on Figure 1, indicates that the average result of daily tests 1 was 60.36, the average daily test for 2 was 64.33 and the average for the 3 tests was 63.45 . From these problems, it is necessary to provide guidance, practice, question and answer, discussion, and provide experiences in social studies learning in class, especially HOTS that students have. Responding to the problems that have been described, it is necessary to make changes in the social studies learning paradigm for elementary school students. Learning should be able to direct students to facts, concepts, phenomena, and problems faced in everyday life, so that they can actively build and interpret everything properly and will benefit their lives now and in the future.

Skills in thinking can be developed with special treatment to train thinking processes to enter long-term storage memory, so that the knowledge gained will be more meaningful, including learning in 
class V on social studies learning content (Setiawan \& Iasha, 2020a). The question card game is a variety of media in learning that is made to foster student interest in learning, this is done according to the results of longitudinal research by Rita Dunn (in DePorter, 2011), everyone has different learning styles, and learning styles that involve visualization the object will make it easier for students to learn.

Selection of the use of media to facilitate students to learn while playing so that they learn according to the demands of their development. The selection of this media also seeks to balance the right brain and left brain, namely understanding concepts and fostering student creativity, so that students can develop knowledge, interact with friends, then develop social, emotional, physical, and motor skills, language, and cognition can also develop properly which functions also to construct an increase in student HOTS (Windiyani et al., 2019).

The question card game that is applied to social studies learning to improve student HOTS is done with each card inserted with an image and text as an explanation of the concept of the material presented and each card has a pair that matches the image and text Students collaborate to find a partner while learning a certain concept or topic in a fun atmosphere. Each question card and answer card has an appropriate relationship between the reading and the material presented. This treatment is carried out to help find the relationship between the questions and answers and to prove that there is a link for students to relate any information found, it can further construct students' HOTS so that there is an increase.

Based on the background of the problem above, it is necessary to research to determine the relevance of question card games in increasing the HOTS of fifth-grade elementary school students in social studies learning.

\section{Method Research}

The research method used in this research is action research or in Indonesian, action research. The action research used in this research refers to one model, namely Kemmis and Mc Taggart.

The research design used is following the principles of action research. This action research was conducted as an effort to improve HOTS in social studies learning through the application of question card games.

The implementation of action research consists of 4 (four) basic stages that are interrelated and continuous, namely (1) planning, (2) acting, (3) observing, and (4) reflection (reflecting).

This research was conducted at SDN Kranji XVI Bekasi City. The research subjects were class V, totaling 30 students, consisting of 16 males and 14 females. The 30 students consistently attended the research process, so that they were relevant to be research subjects.

The focus of this research is to increase HOTS in social studies learning on natural disasters. The research focus was also aimed at grade $\mathrm{V}$ elementary school students through the application of question card games in social studies learning.

The data collection instrument is a tool used to collect data. In this study, instruments were developed to collect, complete, and compare data, namely observation sheets to observe teacher and student activities in social studies learning and questions to measure student HOTS.

The data processing process carried out in this study is the technique of qualitative data analysis and quantitative data analysis. The process of qualitative data analysis of the observation data. The process of qualitative data analysis begins with collecting and classifying data, selecting and focusing the data, then organizing it by describing it in narrative form. The process of quantitative data analysis was carried out by analyzing student HOTS data on social studies learning from the results of the evaluation that had been carried out in each action, then looking for the average of each cycle. 
The success in achieving the goal can be seen from the success of the teacher in teaching completely, namely $100 \%$, the success of the student, which is $85 \%$, and fulfilling the minimum completeness criteria of 73 . If the learning has achieved the targeted results, then the research is said to be complete and not continue to the next cycle.

\section{Result and Discussion}

\section{Result}

\section{Research Planning}

At the planning stage, the researcher designed a social studies lesson that applied the question card game in the lesson plan. The learning metrics used are natural disasters with sub-natural disasters that occur in Indonesia and neighboring countries, types of natural disasters, ways of dealing with natural disasters, and types of assistance provided to victims of natural disasters.

\section{Cycle I}

The first cycle of action was carried out on 13, 15-17 January 2020. In the first cycle, there were several findings. The first meeting was held on Monday, January 13, 2020. Implementation of science learning is still not optimal. Learning is still a teacher center in nature and still does not motivate students to actively coordinate with each other in the learning process. As for student activities, researchers still found students who were not focused on carrying out learning, had not been actively involved in learning, when asking questions were still whispering and when discussing, not all students carried out discussions. Therefore, efforts are still needed to correct existing deficiencies, and it was decided to continue the action in cycle II by making appropriate revisions and continuing the material in cycle II.

\section{Reflection Cycle I}

The results of the reflection carried out by researchers and observers in cycle I with four meetings were that students had not been active in giving opinions, had not been optimal in developing HOTS in analyzing, evaluating, and creating, and had not been optimal in coordination to collaborate with other students so that researchers made improvements as follows.

a. Making emoticon assessments for each student to increase student involvement in the learning process to be implemented.

b. Improve the instructions given for packaging the question card game.

c. Assessing and discussing the work results of each student so that students know mistakes in doing the given assignments also have an effect on students who are not involved in the implementation of learning.

d. Train students in HOTS by encouraging students' ability to access information, analyze, evaluate, and create, to achieve targets.

e. Stimulate students to dare to give or express opinions with habituation.

f. Directing students to be serious in observing any information found. Therefore, the teacher will give rewards to students who can carry out their assignments properly and correctly.

g. Pay attention and direct students to be active and interact so that all students can increase HOTS.Berdasarkan perolehan nilai siswa pada siklus I, siswa yang tuntas berjumlah 20 orang atau $66,67 \%$ dengan nilai rata-rata keterampilan proses siswa yaitu 70.94. Hasil observasi kinerja guru dan aktivitas siswa pun belum memenuhi target karena secara berurutan hanya memperoleh 
persentase $84.09 \%$ dan $75 \%$. Hal tersebut menunjukkan bahwa keterampilan proses siswa masih rendah.

\section{Cycle II}

The second cycle action was carried out on February 3, 2020, and February 5-7, 2020. In the second cycle there were several findings, namely:

a. In observing activities to obtain information, students appear conducive, concentrate, and record important information when observing. Students also look happy and regularly carry out the question card game.

b. Students are actively involved in discussing and analyzing the information that has been collected from the question card game. Each group exchanges opinions and works together in groups. Students are also able to assess the work of other groups. However, two students had difficulty participating in group activities. It is known that students are indeed difficult to participate in learning activities.

c. Students can be directed to pay attention to the groups that appear in front of the class and several students can clarify the information obtained from the groups that appear.

d. In the previous cycle, students experienced difficulties in analyzing, evaluating, and creating activities. However, in cycle II the teacher improved student learning activities by instructing students to pay attention to the parts of the activity carefully.

\section{Reflection Cycle II}

Overall, social studies learning in natural disasters by using question card games was carried out well. However, there are deficiencies in the learning that has been carried out in cycle II. Based on the average value obtained in cycle II, namely 79.69 with 26 students who completed or $86.67 \%$ which was supported by the results of observations of teacher performance and student activity that reached the target of $100 \%$, the research carried out was deemed sufficient and does not require additional cycles. Here are how many things the researcher must pay attention to, namely, the researcher needs to communicate more clearly each stage in social studies learning by applying a question card game to increase student HOTS.

\section{Discussion}

Implementation of social studies learning to increase student HOTS through the application of question card games in class V SDN Kranji XVI Bekasi City with material limitations of proven natural disasters. The research data proves that students' HOTS can increase using the application of question cards, as shown in Table 1.

Table 1. Recapitulation of Pre-Cycle, Cycle I, and Cycle II Evaluation Test Results

\begin{tabular}{|l|l|l|l|}
\hline Students' Activity & Pre Cycle & Cycle I & Cycle II \\
\hline Average value & 62.71 & 70.94 & 79.69 \\
\hline Completeness & $33 \%$ & $66.67 \%$ & $86.67 \%$ \\
\hline
\end{tabular}

Based on Table 1, the comparison of students' HOTS results through the application of the question card game increased in each cycle, but a significant increase occurred in cycle II. This shows that students have reached the minimum completeness criteria, the action is stopped in cycle II. 
Assessment of process skills was carried out by analyzing each learning indicator on each subject. There was an increase that occurred from cycle I to cycle II. Students who reach the minimum completeness criteria are 26 students.

In the pre-cycle, the students' average score was only 62.71 with $33 \%$ classical completeness. In Cycle I, the students' average score was 70.94 with classical completeness of $66.67 \%$. In cycle II, the students' average score was 79.69 with classical completeness reaching $86.67 \%$. The increase in student HOTS is in line with the results of research by Suwarsi, et al. (2018) which showed that there was an increase in HOTS through question card games, but in his research, it was aimed at grade VIII students.

The increase in student HOTS results was influenced by several factors, including during learning activities in cycle II, students understood the subject matter more easily than in pre-cycle and cycle I. Also, students were actively involved and were able to coordinate in learning activities starting from student attention, courage asks and answer teacher questions, so that students are better able to do evaluation questions. These results indicate that the improvement of learning, especially the increase in student HOTS about natural disasters can be achieved.

The increase in HOTS was also supported by the results of observations of teacher performance and student activities that increased from cycle I to cycle II, as shown in Table 2.

Table 2 Recapitulation of Teacher and Student Activities in Social Studies Learning to Increase Student HOTS by using Question Card Games

\begin{tabular}{|l|c|c|c|c|}
\hline \multirow{2}{*}{ Data Resources } & \multicolumn{2}{c|}{ Cycle I } & \multicolumn{2}{c|}{ Cycle II } \\
\cline { 2 - 5 } & Jumlah & $\%$ & Jumlah & $\%$ \\
\hline Teachers' Observation Form & 37 & $84.09 \%$ & 44 & $100 \%$ \\
\hline Students' Observation Form & 27 & $75 \%$ & 36 & $100 \%$ \\
\hline
\end{tabular}

This increase confirms that learning problems in the classroom, especially those related to student HOTS, can be pursued using one of the learning techniques, namely the question card game.

The learning process in elementary schools, especially in social studies learning, is not always effectively packaged using a reliable method that is assumed to be always relevant. The material to be delivered is different as well as the achievement of competencies afterward which are mastered by students so that each lesson has different needs.

The research conducted, identified social studies learning problems that were difficult to achieve for their effectiveness in increasing student HOTS in natural disaster material. HOTS was one of the achievements that had to be addressed immediately because learning in essence does not always measure results, but the process must also be considered.

HOTS, which is constructed by the teacher in the learning process, is expected to facilitate the teacher being able to facilitate students to apply skepticism in their daily life. Students can find information, select information, analyze information, evaluate information to determine decisions after processing valid information. as Kurniati et al (2016) emphasizes that HOTS can facilitate students to do reasoning, analysis, evaluation, and creation well.

The application of HOTS depends on the ability of the teacher to formulate questions that will require students to think at a higher level so that students can solve problems. So the application of HOTS in the learning process can encourage students to be more critical, creative, and can solve problems. The learning process in the classroom should be started by stimulating students to think more actively about the real problems that have been experienced by students. In that way, students are not only treated to ready-made theories and formulas, but students are trained and accustomed to solving problems during the learning process. 
The problem in the form of low HOTS of students in social studies learning requires alternative solutions that are relevant in solving it. An alternative solution is to use a question card game. This question card game has been planned to overcome student difficulties based on consideration of the problems found during initial data collection. HOTS of students can be increased through the application of question card games because learning is carried out at a stage that matches the criteria of elementary schools. According to Berlina in Tarjo (2012), question cards are a means so that students can learn to be actively involved in learning activities, think actively and critically in learning innovatively to find ways or proof of the theory.

Games make learning more interesting and motivate students to study harder and most importantly games can make students enjoy learning. Lepper, Greene \& Nisbett (in Wan \& Chiou, 2007) state that learning is strongly influenced by the extrinsic motivation to meet learning targets. Extrinsic motivation can be in the form of games that can motivate students as well as explore curiosity, exploration, desire to participate, abilities, goals, and plans through fun activities.

The use of question card games in learning can provide experience for students in finding information and also evaluating the information obtained so that valid decision are obtained. This is clearly expressed by Deci et al \& deCharms (in Wan \& Chiou, 2007) when someone plays a game of eating they will get experience. This is in line with social studies learning that learning does not emphasize the results, but it keeps the process of meaningful experiences.

Social studies learning requires student involvement in it and this is following the stages of student learning in elementary schools, including constructing information through meaningful activities to achieve learning targets. The superiority of the question card game is proven to be used to develop students' thinking and learning abilities which were manifested in this study by the increase in student HOTS.

This evidence proves that the implementation of social studies learning using question card games can overcome student difficulties in increasing HOTS.

\section{Conclusion}

The increase in HOTS of fifth-grade students of SDN Kranji XVI Bekasi City in natural disaster material after being given learning using a question card game which was initially on the HOTS of students with a percentage of $33 \%$ had not succeeded in reaching KKM (Minimum Completeness Criteria), but after learning with card games questions, and a series of tests that have been carried out, in the implementation of cycle 1 and cycle 2 HOTS students increased, namely the percentage of students' science process skills who achieved KKM reached $66.67 \%$ in cycle I and $86.67 \%$ in cycle 2 . Process skills acquired by students were classical as well has exceeded the specified standard, namely $85 \%$, so the conclusion that can be drawn by the researcher is that the application of the question card game can increase the HOTS of class V students in social studies learning. The activities of teachers and students during the learning process using question card games have experienced a very good increase. From the implementation of action cycle 1 to the implementation of action cycle 2, the observed indicators of teacher and student activity have been implemented properly. In the implementation of cycle 1, not all indicators are implemented properly, there are several weaknesses in the application of the question card game. Initially, the teacher performance and student activities in the first cycle of learning reached a percentage of $84.09 \%$ and $75 \%$, but after the implementation of corrective actions in cycle 2 , the teacher's performance and student activities which were expected to be achieved well experienced a very good increase in cycle II, namely to be $100 \%$. So it can be concluded that the application of the question card game in social studies learning in class $\mathrm{V}$ is carried out well and the achievement of complete learning is the indicator in the application of the question card game. 


\section{References}

Chin Seng, W. \& Wen Bin, C. (2007). The Motivations of Adolescents Who are Addicted to Online Games: a Cognitive Perspective. Adolescence, 42 (165).

DePorter, B. (2011). Quantum Teaching. Bandung:PT Raja Grafindo Persada.

Kurniati, D., et, al. (2016). Jurnal Penelitian dan Evaluasi Pendidikan. Kemampuan Berpikir Tingkat Tinggi Siswa SMP di Kabupaten Jember dalam Menyelesaikan Soal Berstandar Fisa. Jurnal Penelitian dan Evaluasi Pendidikan, 20 (2).

Lewi, Zulkardi, dan Aisyah. (2009). Jurnal Pendidikan Matematika: Pengembangan Soal untuk mengukur Kemampuan Berpikir Tingkat Tinggi Pokok Bahasan Barisan dan Deret Bilangan di Kelas IX Akselerasi SMP Xaverius Maria Palembang, Jurnal Pendidikan Matematika, 4 (2).

Sari, Y., Luvita, R. D., Cahyaningtyas, A. P., Iasha, V., \& Setiawan, B. (2020). Pengaruh Metode Pembelajaran Struktural Analitik Sitentik terhadap Kemampuan Menulis Permulaan di Sekolah Dasar. Jurnal Basicedu, 4(4), 1125-1133.

Sari, Y., MS, Z., Iasha, V., \& Kalengkongan, J. (2020). PENINGKATAN KEMAMPUAN BERPIKIR KRITIS MELALUI MODEL AUDITORY, INTELLEKTUALY, REPATITION (AIR) BERBANTUAN KOMIK IPA DI SEKOLAH DASAR. Refleksi Edukatika: Jurnal Ilmiah Kependidikan, 11(1), 121-126. https://doi.org/10.24176/re.v11i1.5045

Setiawan, B. (2015). Eksperimentasi Model Pembelajaran Problem Solving dengan Pendekatan Peer Tutoring Berbasis Metode Pembelajaran Eksperimen dan Demonstrasi pada Materi Fluida Statis Siswa Kelas X MIA SMA Negeri 1 Banyudono.

Setiawan, B., \& Iasha, V. (2020a). Corona Virus Disease 2019: The Perspective Opinion From PreService Elementary Education Teacher. Education, Sustainability \& Society, 3(2), 33-36. https://doi.org/10.26480/ess.02.2020.33.36

Setiawan, B., \& Iasha, V. (2020b). COVID-19 PANDEMIC: THE INFLUENCE OF FULL-ONLINE LEARNING FOR ELEMENTARY SCHOOL IN RURAL AREAS. JPsd (Jurnal Pendidikan Sekolah Dasar), 6(2), 114-123.

Setiawan, B., Juniarso, T., Fanani, A., \& Iasha, V. (2020). Pembelajaran Online Di Masa Pandemi Covid19: Pengaruhnya Terhadap Pemahanan Konsep Fisika Mahasiswa. Jurnal Pendidikan Dasar, 11(02), 230-236.

Setiawan, B., Rachmadtullah, R., \& Iasha, V. (2020). Problem-Solving Method: The Effectiveness of The Pre-service Elementary Education Teacher Activeness in The Concept of Physics Content. Jurnal Basicedu, 4(4), 1074-1083.

Sudrajat, A., Iasha, V., \& Femayati, F. (2018). The Influence of the Use of Cooperative Learning Model Jigsaw \& Two Stay Two Stray and the Learning Interest Result on 5th Grade Social Science. ICEAP, 2(2), 28-33.

Suwarsi, et, al. (2018). Prisma Prosiding Seminar Nasional Matematika. Meningkatkan Keterampilan HOTS Siswa melalui Permainan Soal dalam Pembelajaran PBL, Journal.Unnes.ac.id [Diakses Online] pada tanggal 1 Januari 2020.

Windiyani, T., Boerieswati, E., \& Sumantri, M. S. (2019). Improve Indonesian Language Writing Skills using Educational Multimedia Games for Elementary School Students. International Conference on Education, Language, and Society.

Yetti, E., Yufiarti, Pramitasari, M., Suharti, Iasha, V., \& Setiawan, B. (2021). The Influence of Dance Instructional Strategy and Teacher's Pedagogy Competence on Classroom Climate. Elementary Education Online, 20(1), 642-650. https://doi.org/10.17051/ilkonline.2021.01.54 
Tarjo, 2012, “Media Pembelajaran dengan Kartu Soal”. (on-line), Tersedia di http://adzjiotarbiyah.blogspot.com/2012/03media-pembelajaran-dengankartu-soal.html (diakses 16 Desember 2019).

\section{Copyrights}

Copyright for this article is retained by the author(s), with first publication rights granted to the journal.

This is an open-access article distributed under the terms and conditions of the Creative Commons Attribution license (http://creativecommons.org/licenses/by/4.0/). 